\title{
Factors affecting the enrolment rate of students in Higher Education Institutions in the Gauteng province, South Africa
}

\author{
Mpho Joyce Matsolo, Wilson C Ningpuanyeh and A Sathiya Susuman
}

\begin{abstract}
The purpose of this research is to investigate and analyse higher education institutions' enrolment and drop-out rates within the Gauteng province, South Africa. Large-scale secondary data from the General Household Survey, obtained from Statistics South Africa (2012) were used. This study's findings show that finance, orphan-hood, transport to the higher education institutions and, to a lesser extent, unplanned pregnancies, are some of the main factors that affect the enrolment rate of students. This study hopes to be useful to policy-makers, research managers and other decision-makers within the higher education (HE) landscape.
\end{abstract}

\section{Introduction}

In South Africa, research has revealed that since 1994 the number of students enrolled in higher education institutions has improved tremendously (Steyn, \& De Villiers, 2006). Higher education and training consist of certificates and diplomas and undergraduate and postgraduate degrees up to the level of doctoral degrees. South Africa has a vibrant higher education sector, with more than a million students enrolled in the country's 24 state-funded tertiary institutions. Of those institutions, 11 are traditional universities, five are universities of technology, and six are comprehensive institutions. Two new universities have been built in the Northern Cape and Mpumalanga provinces, where there were no higher education institutions previously. The introduction of the two institutions in these provinces will undoubtedly boost enrolment rates since the majority of students will come from the home province.

Higher education institutions in South Africa are in the process of finding innovative ways to combine different qualifications, curricula, teaching and learning styles within the University of Technology and its constituent parts. Notably, since 2000, South African students' enrolment has grown at a rate of $4.2 \%$ per year on average (Steyn, \& De Villiers, 2006). This figure takes into account the negative growth which took place between 2004 and 2005 during the merger of higher education institutions. Subsequent to that, between 2005 and 2009, there was a noticeable decline of up to $2.3 \%$ per annum. Unexpectedly, between 2010 and 2011 the figure increased up to 6.2\% with 55,000 additional students registered in the system (Steyn, \& De Villiers, 2006). The country has acknowledged that it is largely through education that economic growth will improve - giving people a way out of 
poverty (Annual Report Council on Higher education). Furthermore, policies of higher education have been outlined to obtain better insight about what the government intends to do in order to improve higher education conditions and answer concerns.

In 2000, the gross enrolment rate in higher education institutions, that is the enrolment in higher education institutions regardless of age as a proportion of 20-24 years old in the population was discovered to be 12.9\% (Statistics South Africa, 2012). Therefore, by 2001 the National Policy for Higher Education - which provided the implementation framework for transforming the higher education system - set the participation rate target at $20 \%$ over a 10 to 15 year period (Ministry of Education, 2001). Between 2000 and 2006, higher education enrolment increased by $1.6 \%$. It was therefore $14.5 \%$ in 2006 , although it dropped from a high of $16.1 \%$ in 2004 and stood at $16.3 \%$ in 2007 (Ministry of Education, 2001).

While the new higher education policy intends to improve the quality of education programmes offered at higher education institutions that have been created as a result of mergers, it will also reduce the perception of inadequacy in higher education among many in the labour market. However, the challenge of resources requires urgent attention, particularly in the historically black universities (Letseka and Maile, 2008). Higher Education South Africa's (HESA) systems and policy considerations for the next 10 years are to:

- achieve an appropriate balance between institutional autonomy, academic freedom and public accountability;

- $\quad$ arrive at an adequately funded higher education system;

- $\quad$ achieve quality levels comparable to the best in the world;

- $\quad$ develop institutional diversity in terms of self-differentiation;

- $\quad$ advance transformation, social cohesion, non-discrimination and freedom of speech and association;

- $\quad$ strengthen institutional responsiveness and relevance (HESA, 2009).

\section{An outline of the problem}

South African higher education institutions face serious challenges - particularly challenges such as low enrolment levels and high drop-out rates. According to the National Plan for Higher Education (NPHE) compiled by the Department of Education in 2001, the country's graduation rate of approximately $15 \%$ is one of the lowest in the world. This is of particular concern, given the huge number of first-year students enrolled at higher education institutions. The drop-out rate may also lead to a critical shortage of high-level skills in the labour market. In combination, these factors are likely to act as a major impediment to the government's economic development goals.

Various studies have revealed the stark realities of racial inequalities in the higher education sector. Looking at the low graduation rates, black students were more affected than others (Letseka and Maile, 2008). According to the Department of Education

\section{http://repository.uwc.ac.za}


(2004/2005), black Africans and coloureds are the population groups that bore the brunt of exclusion by the apartheid education policies and legislation, and they continue to lag behind in education success rates. For this reason, the National Planning Commission (NPC) recommended that the participation rate for black students be increased to over $30 \%$ and that their enrolment in higher education institutions, including private ones, be increased from 950,000 in 2010 to more than 1.6 million in 2030, a 70\% increase (NPC, 2011sorted).

Furthermore, as late as 1993, provision of educational funding was racially skewed and quite unequal. In that year, the apartheid regime allocated R4504 for the education of a white pupil, R3625 per Indian pupil, R2855 per coloured pupil and a paltry R1532 per black African pupil (Education Statistics in South Africa at a Glance, 2001-2004sorted). In higher education, steep university fees contribute to the continued under-representation of black students (and this group is most likely to drop out) - which threatens to replicate racial inequality in higher education well into the future. The National Student Financial Aid Scheme (NSFAS), regarded as a successful scheme established by the government to assist students from poor and disadvantaged families with academic ability, provides loans and bursaries to eligible first-time students entering and continuing at universities and public Technical and Vocational Education and Training (TVET) colleges throughout the country. As a matter of fact, the NSFAS loans to students increased fivefold between 1995 and 2005 .

Early in 2016, the Higher Education and Training Minister, Blade Nzimande, announced that the NSFAS budget would increase from R9.5 billion in 2015 to R1o billion in the 2016/17 financial year. Briefing journalists in Pretoria, the minister also said that the allocation was an increase compared to 2014's R8.3 billion loans. He also mentioned that NSFAS would fund 205,000 eligible first-time-entering-and-continuing students at universities and 200,000 students at Technical and Vocational Education and Training (TVET) colleges. Against this background, a further analysis is needed to learn about the factors affecting enrolment rates at higher education institutions and provide lessons learned from the literature review. In addition, analytical tools will illuminate the current limitations facing the higher education sector.

\section{Objectives of the study}

The main aim of the study is to understand the reasons behind the fact that many students at higher education institutions are unable to enrol or fail to complete their studies. In addition, this study will attempt to profile such students according to their enrolments as well as drop-out rates. The study will also look into the enrolment of students according to their designated population groups, since some universities used to enrol only white students during the dispensation/apartheid era.

The study will also look into the proportion of students receiving bursaries and loans and it will also consider the type of households which pay tuition fees. It is also important for the researcher to understand if unplanned pregnancies, orphan-hood and transport problems

\section{http://repository.uwc.ac.za}


can impact on the enrolment figures. The distribution of students enrolled at higher education institutions according to population group, as well as gender, will also be investigated.

\section{Research questions}

This research attempts to answer the following questions:

1. Can student finance affect the enrolment or drop-out rates of students at higher education institutions?

2. Why are many students not able to register or complete their higher education?

3. How can the high drop-out figures be reduced?

\section{Limitations of the study}

The largest limitation of this study is that the GHS questionnaire did not ask questions about students' drop-out rate. Subsequently, an additional questionnaire had to be developed to learn more about the drop-out rates at higher education institutions. Furthermore, it was difficult to find localised literature that focused specifically on higher education institutions in the Gauteng province.

This section aims to synthesise various pedagogical studies and articles on higher education enrolment. During the apartheid regime, for instance, non-white individuals were seen largely as different, as well as inferior, to white individuals in South Africa (Ratele and Shefer, 2003). These apartheid-constructed differences brought discrimination among races, since some felt more privileged or superior to others. Schooling was generally better for white students, whilst Indian and coloured education was (comparatively) better than black education (Morrow, 1990). Whites largely enjoyed the privileges of accessing and enrolling at institutions of their choice whereas their counterparts had less exposure and also struggled to access the institutions. A lack of funding was one of the biggest issues which faced potential black South African students with the intention of pursuing tertiary studies. The post-apartheid government has made such an enormous transformation by introducing NSFAS loans (previously called TEFSA) as a solution to indigent students who wish to pursue higher education.sorted

\section{Higher education enrolment}

Compared to most countries, education in South Africa gets quite a large slice of public money, usually around $20 \%$ of the total state expenditure. With this, many disadvantaged students can afford the opportunity to access higher institutions, in contrast to the situation that existed in the former white-only universities and institutes. More funds are always needed to address the huge backlog left by the apartheid education system. Education plays a significant and pivotal role in eliminating poverty, since it is the most significant way of investing in human capital, and can lead to higher earnings (Nimubona and Vencatachellum, 2007). Tertiary education attainment has numerous benefits, some of which are to contribute to the country's greater skills base, as well as increasing savings and

\section{http://repository.uwc.ac.za}


creating greater tax revenue, improving health and technology, and reducing population growth (Bloom et al., 2006; Council on Higher Education, 2008/2009; Makoe, 2006; Mubangizi and Mubangizi, 2005).

It is necessary for the country to encourage more of the constituents of its society to enrol at higher education institutions (Council on Higher Education, 2008/2009). A restructured higher education system should be socially just and equitable in its distribution of resources and opportunities (Department of Education, 2012). Furthermore, Higher Education South Africa (HESA) published a report in 2008sorted revealing that by 2004, direct first-stream funding from the government had dropped to $43 \%$ of the university's income, that is from $49 \%$ in 2000 , while disproportionally the second-stream income from fees rose to $29 \%$, up from $24 \%$ in 2000 . According to the Department of Higher Education and Training, state funding for South African students grew from R2.3 billion in 2008 to R6 billion in 2011 to R8.3 billion in 2014 to R9.5 billion in 2015 (HESA 2008).

South Africa will ensure that its funding for poor students as well as strong performers at the country's universities and colleges increases every year. The budget of 2013 compared to that of 2012, revealed that $\mathrm{R} 5.4$ billion had been allocated to the total programme, which amounted to a 5.3\% increase. Furthermore, R1.9 billion had been set aside for the bursary allocation and this represented a $7.5 \%$ increase. Financial instability in one way or another affects the racial profile of enrolment in most institutions. Student outcomes are, overall, poor, and inequality among institutions and racial groups is very high. The participation rate of whites is well over 50\% compared with $13 \%$ for Africans (Fisher and Scott, 2011Only one). According to the South African Statistics on post school education 2013 (2013), in 1993 nearly half of all students were white, 40\% were African, $6 \%$ were coloured and $7 \%$ were Indian. However, by 2005 the portion of white students had shrunk to $25 \%$ and the African share had grown to $61 \%$. South Africa's student participation rate - the proportion of 18-24 years old in higher education - is fast approaching 20\% (Statistics on Post School education and Training, 2013). But while access to higher education has significantly improved, there are still racial divisions between the participation rates of young people, some $60 \%$ of whites and more than half of Indians enter higher education, but the rate for Africans is only around $11 \%$ and for coloured it is even lower at 7\%. In September 2013, a joint statement by University of KwaZulu Natal, UKZN, and the transformation oversight committee for public universities showed that South Africa's previously advantaged institutions had poor equity indices, but scored well as high-level knowledge producers (Jenvey, 2013). Correspondingly, universities of technology and several formerly disadvantaged institutions produced 'little research, but have a good equity profile' (Govender, 2013).

\section{Gender disparities in higher education institutions}

Gender disparities in various societal organisations and institutions have been the subject of ongoing feminist research initiatives. Institutions of higher learning are no exception to this. In the mid-1990s, gender equity remained a problem in higher education, with more men than women enrolled at South African higher education institutions. Although the apartheid

\section{http://repository.uwc.ac.za}


system was a patriarchal, militarised system that oppressed women in general, the treatment of white women was mitigated by their racial affinity. White women were privileged by legal prescriptions during the pre-1994 historical phase, thus putting them above black women in the hierarchical ordering of the people of South Africa. The majority of white women had access to private education and institutions of their choice, and although they were discriminated against in terms of their gender, they were nonetheless relatively better disposed than their black counterparts who had suffered double oppression (Mathabe, 2009).

It is interesting to note that after 1994, South Africa experienced a large number of female students entering universities. In 1993, the total percentage of women students in South African universities was 43\% whilst in 1999 the percentage increased to 53\%. Male students constituted $57 \%$ in 1993 whilst in 1997 their number decreased to $48 \%$. In the post-1994 era the number of female students surpassed that of male students, especially at an undergraduate level. At this level, it could also be argued that the sharp increase of female students over their male counterparts might not portend well for the future, given that the idea of mainstreaming gender in universities is not to decrease the number of male students but to create parity (Mathabe, 2009).

According to statistics stated during the Commonwealth Association of Universities Conference in Cape Town in 2010, by the year $200053 \%$ of students were women and the proportion went on to rise to $55.5 \%$ in 2007. Presenting his findings to the parliamentary committee, Professor Malegapuru Makgoba said the study 'surprisingly showed' that gender transformation was happening faster in higher education. The percentage share of female students has increased faster than that of male students, which was 55\% and 44\% respectively for the year 2007 (Bunting et al., 2010). Lamdany (2004: 3sorted) asserts that arguments to subsidise higher education in order to increase female enrolment and academic development are weakened in countries where the gender gap is higher in secondary school than in the higher education.

\section{Students' enrolment and dropout}

Higher education in South Africa faces a number of challenges, one of which is the high student drop-out rate. A drop-out rate of $45 \%$ among students undermines the access gains of universities. Financial difficulties are among the most common reasons given by poor black students for not pursuing their tertiary education. According to the student pathways study done by Letseka and Maile (2008), 'first generation' students from low income, less educated families are most likely to drop out. Loans and bursaries do not cover the full costs of study, leaving students struggling to cover living and other costs. This is especially true for those students on the NSFAS loan scheme of whom $35 \%$ of do not complete their studies (HESA, 2008sorted).

In 2005, the Department of Higher Education reported that of the 120,000 students who enrolled in higher education in 2000, 36,000 (30\%) dropped out in their first year of study. A

\section{http://repository.uwc.ac.za}


further 24,000 (20\%) dropped out during their second and third years. Of the remaining $60,000,22 \%$ graduated within the specified three years duration for a generic Bachelor's degree. Subsequently, the department issued a public statement lamenting that the drop-out rate was costing the treasury $\mathrm{R} 4.5$ billion in grants and subsidies to higher education institutions without a commensurate return on investment. It has since emerged that at some institutions the drop-out rate is as high as 80\%. Fowler and Gilfillan (2003) argued that one of the main reasons for student drop out is the fact that students are often not academically and psychologically prepared for tertiary study. The transition from high school to tertiary education, for example, is quite gruelling, with an especially steep learning curve to handle tertiary life socially and academically.

Pierrakeas et al. (2004) argue that unplanned pregnancy or childbearing could be the reason for high drop-out rates. Likewise, Dlodlo, N. (2009) also highlights the way in which unplanned pregnancies increase the risk of dropping out of university or college, as $61 \%$ of the registered students who happen to have children do not finish their education - a figure that is $65 \%$ higher than the rate for those who do not have children. Macfarlane (2006) argues that even when the movement of students between institutions is taken into account, close to $50 \%$ of undergraduates drop out. About one in three university students and one in two Technikon students dropped out between 2000 and 2004 (Letseka and Maile, 2008). Improvement in throughput rates must be the top strategic priority for universities. Among other things, this will allow education to increase the number of graduates disproportionally to the increase in the relatively modest projected expansion of university enrolments (Department of Higher Education and Training, 2012). In 2001, the participation rate target was set at $20 \%$ over 10 to 15 years. Subsequently, the set enrolment rate elicited a need to build two new higher education institutionsn in the Mpumalanga and Northern Cape provinces. However, in 2006 there was a drop in the participation rate to $14.5 \%$ from a high of $16.1 \%$ in 2004. Various factors explain this, with finance being the key.

Moreover, findings from other authors claim that the high drop-out rate among students is simply because students are often not academically prepared for tertiary study, referring to the transition from high school to tertiary education. Subsequently, HESA established a Working Group on Teaching and Learning, which has recommended that a charter be drawn up to improve teaching and learning, recommending that three-year degrees be changed to four years, and emphasizing that academic support programs and NSFAS assistance be strengthened. 
Table I. Percentage data distribution of enrolment by sex.

\begin{tabular}{lllll}
\hline Enrolment (attendance) & & & \\
\hline Sex & & Yes & No & Total \\
\hline Male & No. of students & 2004 & 454 & 2458 \\
& Enrolled & 81.53 & 18.47 & 100.0 \\
Female & No. of students & 1976 & 486 & 2462 \\
& Enrolled & 80.26 & 19.74 & 100.0 \\
Total & Enrolled & 3980 & 940 & 4920 \\
& Per cent & 80.89 & 19.11 & 100.0 \\
\hline
\end{tabular}

Source: Statistics South Africa - GHS 2012.

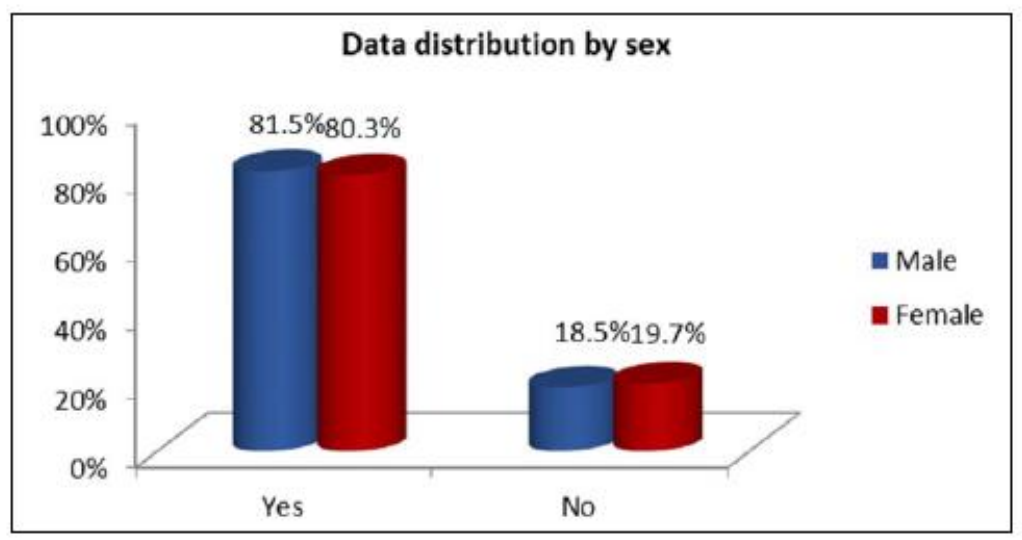

Figure I. Percentage of data distribution by sex. Source: Statistics South Africa (2012).

\section{Data and methods}

The data used in this study is based on the General Household Survey (GHS) produced by Statistics South Africa (2012). The GHS is an annual survey that utilises a face-to-face interview method to collect nationally representative data.

Table 1 and Figure 1 illustrate the data distribution of gender by enrolment. In 2012, the percentage of enrolled males was $81.53 \%$, and the percentage of enrolled females was $80.26 \%$. In order to determine whether the two percentages are statistically different, the ChiSquare test provided below in Table 2 was used.

This paper attempts to unearth the factors affecting the enrolment rate of higher education institutions in Gauteng, focusing on demographics and variables such as finance, distance and transport. The expectation is that these variables will provide constructive results upon completion of the study. This goal will be achieved using the GHS, one of South Africa's largest surveys, which is conducted with a focus on several variables, including education. The study took an empirical approach and primarily used descriptive and inferential statistics for data analysis. 
Table 2. Comparison of higher education institutions enrolment according to race in the $20 \mathrm{II}$ and $20 \mathrm{I} 2$ academic years.

\begin{tabular}{|c|c|c|c|c|c|c|c|c|}
\hline \multirow[t]{2}{*}{ Enrolment } & \multicolumn{2}{|c|}{ Black African } & \multicolumn{2}{|c|}{ Coloured } & \multicolumn{2}{|c|}{ Asian/Indian } & \multicolumn{2}{|c|}{ White } \\
\hline & 2011 & 2012 & 2011 & 2012 & 2011 & 2012 & 2011 & 2012 \\
\hline Yes & 78.2 & 73.6 & 4.1 & 3.2 & 3.4 & 2.0 & 14.4 & 21.2 \\
\hline No & 82.3 & 84.4 & 2.9 & 2.5 & 2.3 & 1.7 & 12.5 & 11.4 \\
\hline
\end{tabular}

Source: Statistics South Africa (2012).

\section{Methods}

Based on the available literature review, there is a link between education, enrolment and attendance variables. The secondary data from General Household Survey (GHS) was utilised for study. Quantitative research methodology is a type of research that is 'based on the measurement of quantity or amount'. A total of 25,361 households (including multiple households) were successfully interviewed during face-to-face interviews, with the response rate of $81.4 \%$. Because the GHS does not provide information on drop-out rates, we developed a questionnaire to gauge the respondents' feelings and perceptions of the dropout rate within the Gauteng province in 2014. In addition, a sample of 100 people was approached at random and provided with a questionnaire for a self-administered interview. The population of interest included both employed and unemployed persons, as well as pensioners and students from the age of 17 years and above. Bivariate, graphical presentations, Pearson's Correlation Coefficients and logistic regression model were used.

The following variables were selected for the purpose of this study:

- dependent variables: enrolment rate;

- $\quad$ independent variables: age; sex; income; mode of transport; reasons for not enrolling; bursary/fee reduction; annual fees paid; distance to the institution.

\section{Ethical considerations}

The study used secondary data from Statistics South Africa, which is public-domain information accessed via the website. ${ }^{1}$ This study does not identify any individual, group, society or community. The information provided in this study can prove useful for both policy-makers and planners. Data used for this study is fully available without restriction.

\section{Results}

The Gauteng Province is the fastest growing province, experiencing a population growth of over 33\% between the 1996 and 2011 censuses, thus making it the province with the largest population in South Africa. The SSA census 2011 has also revealed that overall, 40.6\% of residents have completed high school and $34.3 \%$ managed to complete some higher education.

Figure 2 illustrates the percentage of students who were enrolled in 2012. Approximately $79 \%$ of the people were declared not enrolled, whilst $21 \%$ stated that they were enrolled.

\section{http://repository.uwc.ac.za}


The results raised concerns as to why such a high percentage of young people were not enrolled in higher education institutions. This could be a result of various factors which will be measured against enrolment in the report.

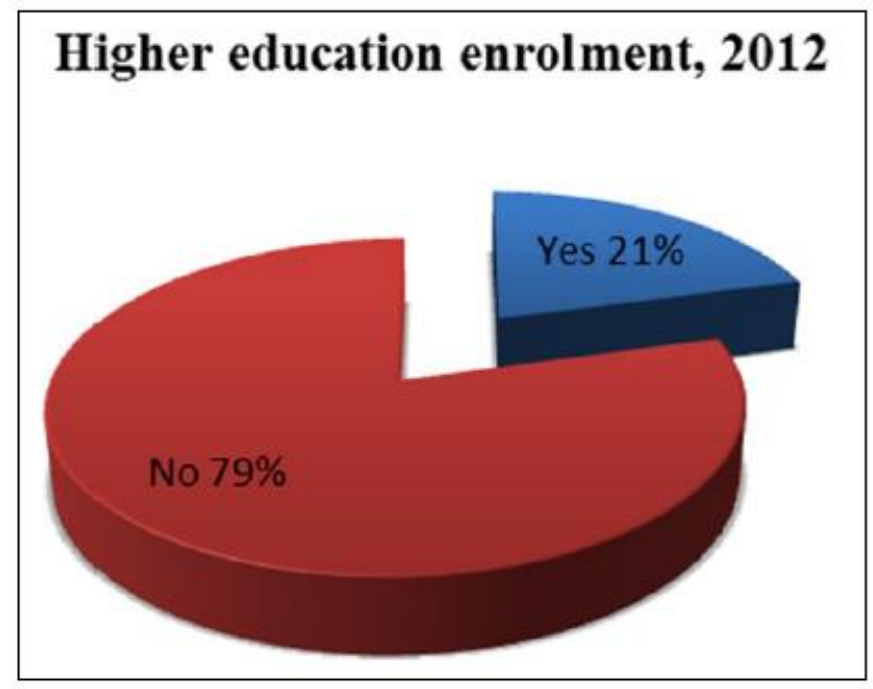

Figure 2. Enrolment in the higher education institutions. Source: Statistics South Africa (2012).

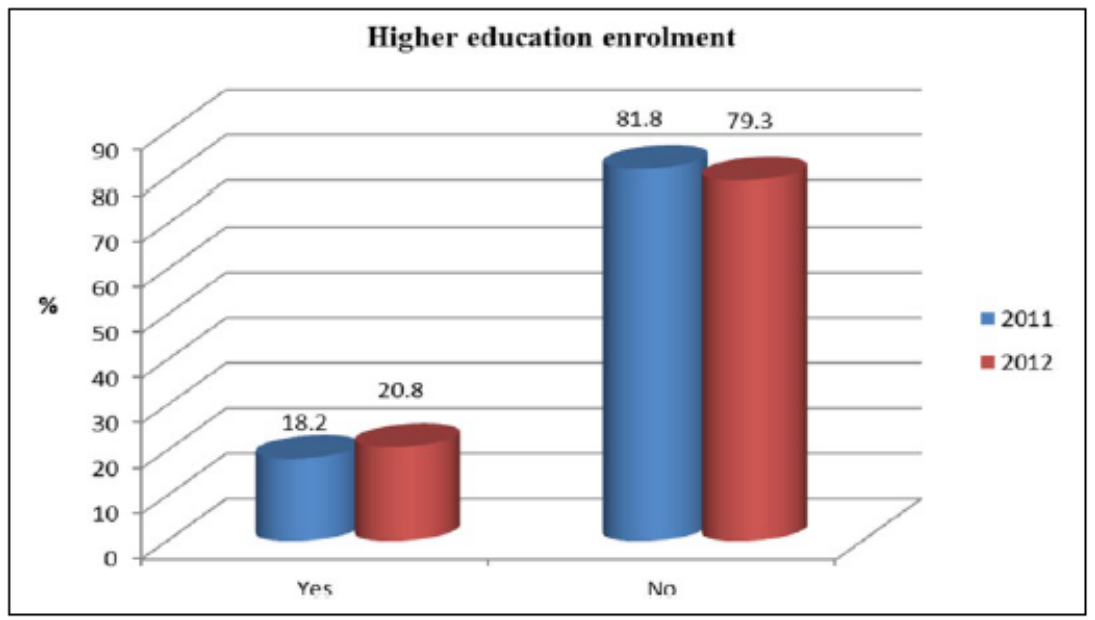

Figure 3. Comparison of higher education enrolment in 2011 and 2012 academic years respectively. Source: Statistics South Africa (2012).

Figure 3 illustrates the enrolment comparison between the 2011 and 2012 academic years respectively. The results show that approximately $21 \%$ of the students were enrolled in the 2012 academic year, whilst 18\% were enrolled in the 2011 academic year. The comparison between the two years clearly shows that there is a problem concerning enrolment. The state of enrolment rate appears similar despite a slight improvement in 2012. The huge percentage of unregistered potential students in both years is alarming and unacceptable. 


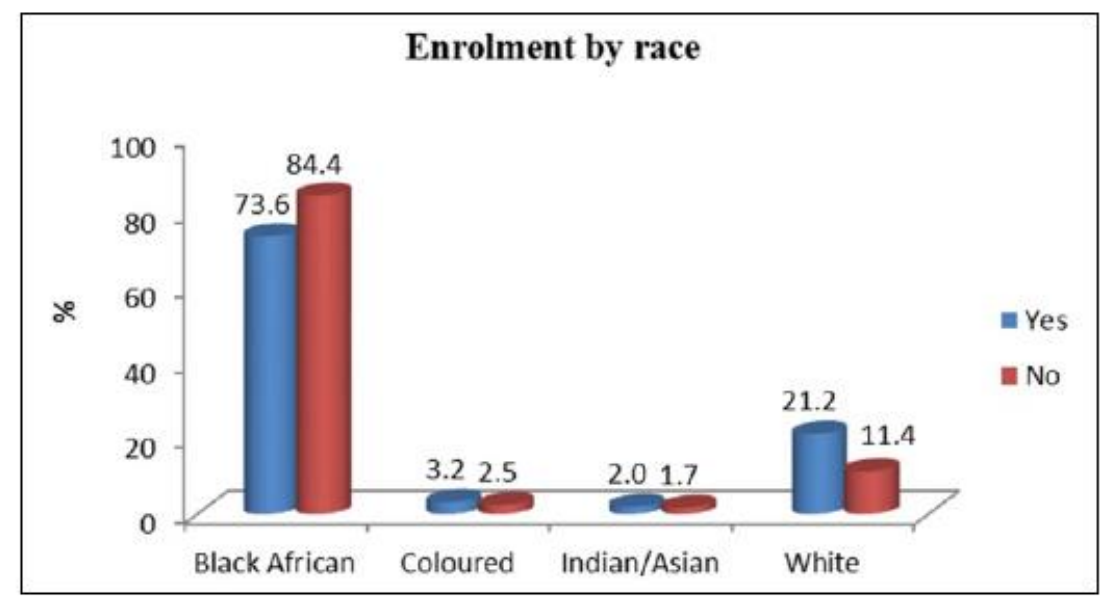

Figure 4. Enrolment percentages by race.

Source: Statistics South Africa (20I2).

Due to the racial disparity experienced in our institutions, a question was asked to identify the percentage difference of enrolment by race. Consequently, Figure 3 illustrates the percentage of students enrolled in the Gauteng province according to their race. Referring to Figure 4, amongst $21 \%$ of the students who were enrolled, $74 \%$ of them were black Africans, followed by $21 \%$ whites. Coloureds and Indians/Asians represented the lowest percentage of the enrolled students in our institutions - represented by $3 \%$ and $2 \%$ respectively. Moreover, it is noticed that from the $79 \%$ of the potential students who were not enrolled, according to Figure 4, above $84 \%$ of them were of black African race, followed by $11 \%$ of whites, whilst coloureds and Indians/Asians were $3 \%$ and $2 \%$ respectively.

The outcomes shown in Figure 4 are not surprising, as it is known that the majority of the country's population is black followed by the coloured population. Whites and Indians/Asians are the smallest population; hence they are represented in smaller percentages. Overall, the results show that there is huge improvement in black African students' enrolment within the country's and province's higher education institutions compared to the previous dispensation.

Table 2 shows a decline in higher education institution enrolment across all South African races with the exception of white, which has increased from 14\% in 2011 to $21 \%$ in 2012. The enrolment of Black African students in higher education institutions reveals a significant drop from $78 \%$ in 2011 to $73 \%$ in 2012 , which leads to an increase in enrolment rate of $2.1 \%$ between the two years. Once again, black Africans will most likely show a higher percentage as they are the majority.

Given the historical background of the country, gender enrolment reveals that, in Gauteng province, $52 \%$ of students who enrolled were males, whilst $49 \%$ were females. Furthermore, $53 \%$ of males and $47 \%$ of females were amongst those students who either dropped out or who have never registered. With regard to gender enrolment between 2011 and 2012, Table 
3 demonstrates an improvement in male enrolment, an increase of about $1.5 \%$ compared to the percentage of females, which dropped from $50 \%$ to $49 \%$ respectively.

A further question was asked following the outcome shown in Figure 5, namely respondents were asked to state reasons why they were not enrolled in higher education. As illustrated, the majority of respondents, $34.3 \%$ to be specific, could not enrol at any higher education institution due to their household responsibilities, work or businesses they were involved in. Precisely the same percentage, $34.3 \%$, indicated that the main reason for not registering at higher education institutions was a lack of finances.

Table 3. Comparison of higher education institutions enrolment by gender between the $20 \mathrm{II}$ and $20 \mathrm{I} 2$ academic years.

\begin{tabular}{llllll}
\hline Enrolment & Male & & & Female \\
\cline { 2 - 3 } \cline { 5 - 6 } & 2011 & 2012 & & 2011 & 2012 \\
\hline Yes & 50.0 & 51.5 & 50.0 & 48.5 \\
No & 51.4 & 52.6 & & 48.6 & 47.4 \\
\hline
\end{tabular}

Source: Statistics South Africa (2012).

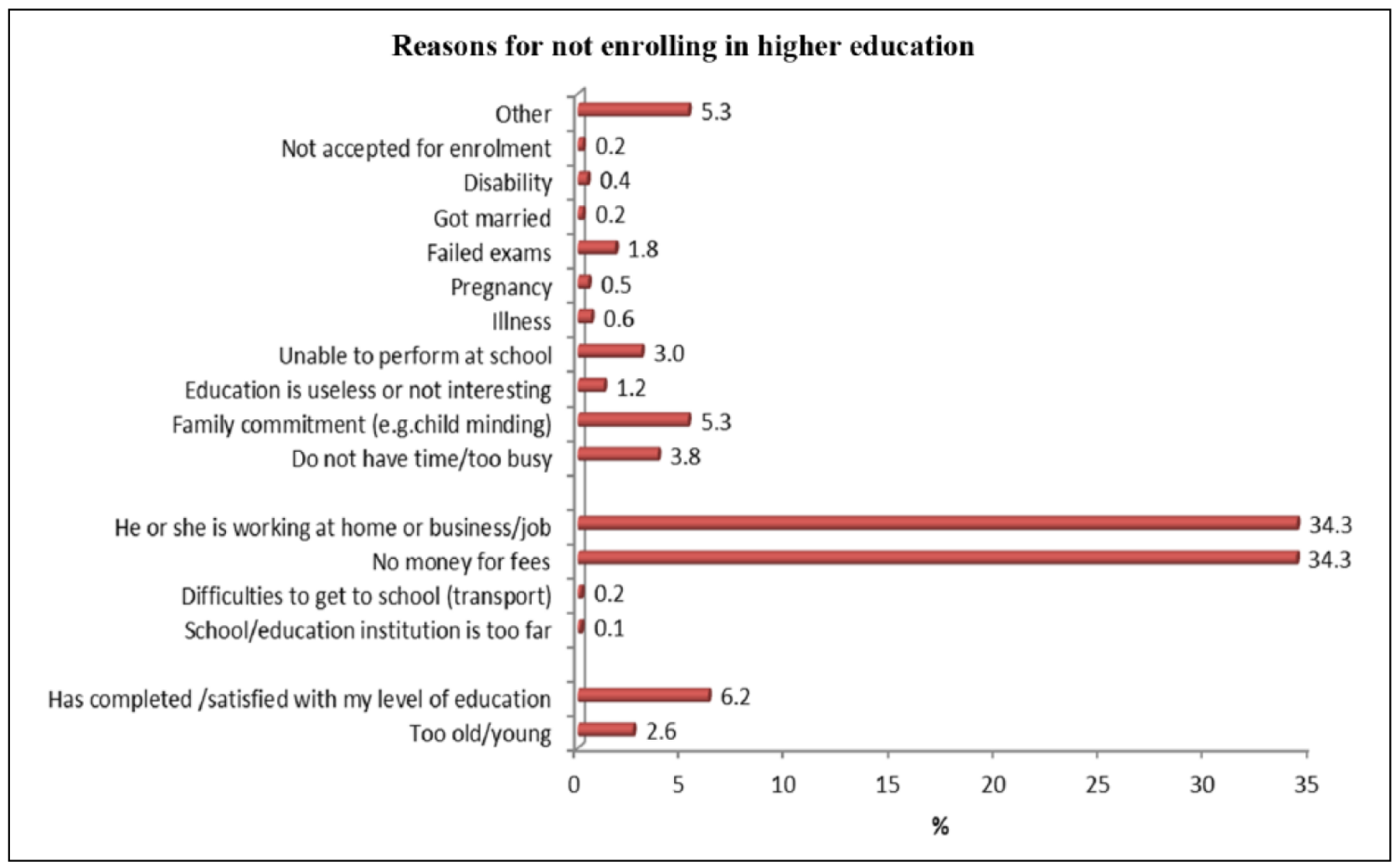

Figure 5. Reasons for not registering in higher education institutions. Source: Statistics South Africa (2012).

It is interesting to note that $6.2 \%$ of the respondents saw no need to further their studying, as they were satisfied with their level of education.

\section{http://repository.uwc.ac.za}


Of the remaining participants, $5.3 \%$ had home or communal commitments such as childminding, whilst $3.8 \%$ revealed that they had no time to study as they were occupied. Pregnancies did not seem to be playing any significant role in preventing potential students from furthering their studies, hence the low figure of $0.5 \%$. The same goes for transportation and distance to institutions with $0.2 \%$ and $0.1 \%$ respectively. Beyond other reasons provided in Figure 5, a lack of finance and work commitments appear to be the main hindrances preventing many potential students from furthering their studies at the tertiary level.

Respondents were asked in Figure 6 about the mode of transport they use to attend registered higher education institutions. The majority of the respondents, about $31 \%$, indicated that they normally walk, whilst $25 \%$ specified that they make use of minibus taxis. Quite a significant number of people, about 20\%, use private transport to get to their institutions. Approximately $11 \%$ of students are reported to use a private vehicle hired by their parents, taking them to and from their designated institutions on a daily basis.

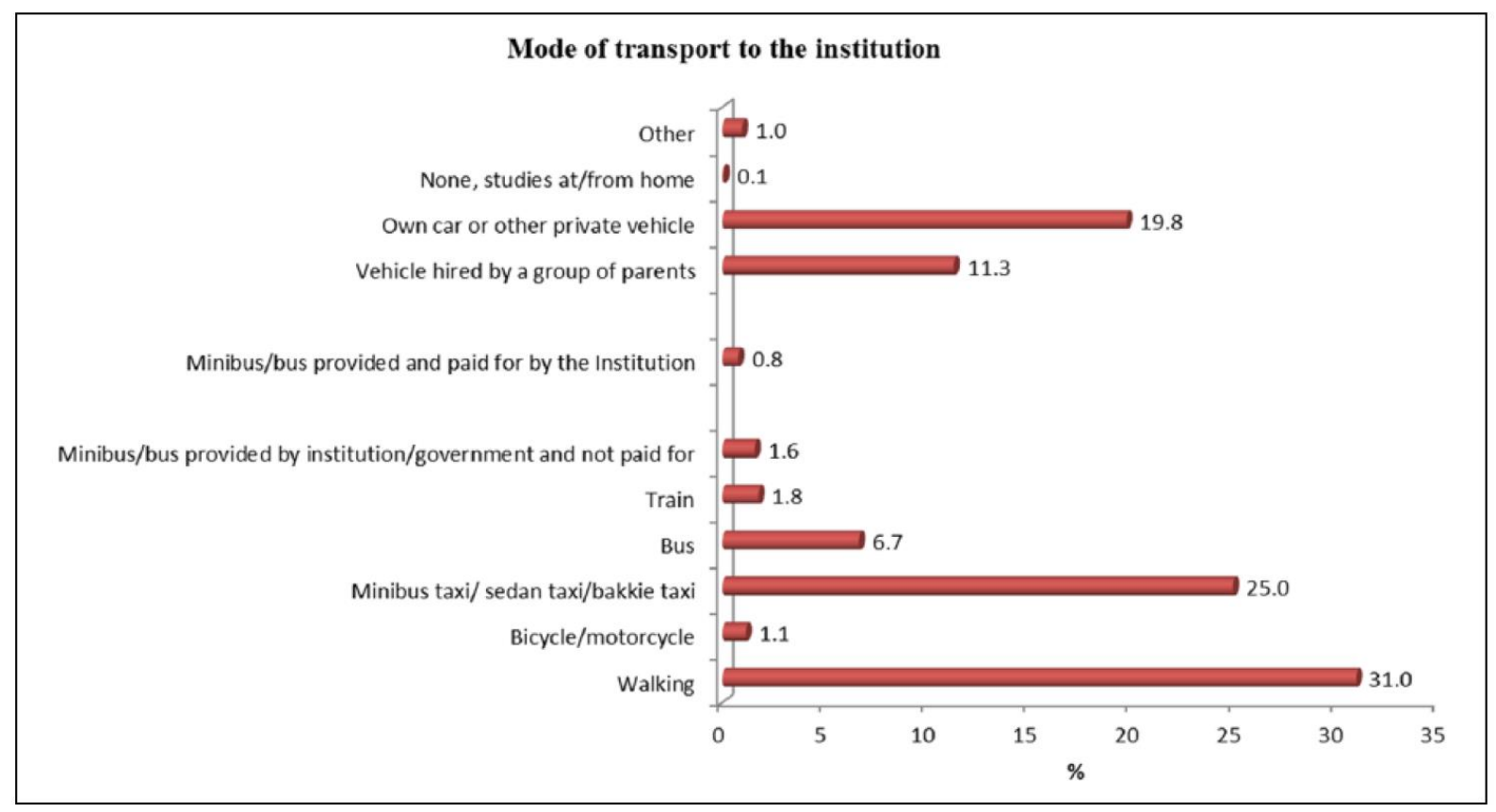

Figure 6. Students' mode of transportation to the higher education institutions. Source: Statistics South Africa (20I2).

It is strange to find that only $1 \%$ of the students use the buses provided and paid for by their respective institutions, whilst $2 \%$ use similar kind of buses but not funded by the institutions.

Figure 6 shows the distance travelled by the respondents to their institutions of learning. Notably, $41 \%$ of the respondents travel a distance of $15-30$ minutes to their institutions. Approximately $28 \%$ of the respondents travel for about 31-60 minutes to their institutions, whilst $27 \%$ of the respondents claim to live closer to their institutions as it takes less than 15 minutes for them to arrive at their institutions. Only $0.3 \%$ of the respondents mentioned

\section{http://repository.uwc.ac.za}


that it normally takes more than 90 minutes to travel to their higher education institutions. The above data indicate that the majority of students are not residing too far from their institutions.

According to the data gathered, $92 \%$ of the respondents reported that they do not receive any financial assistance, whilst $8 \%$ declared that they do. The above results indicate that the majority of students pay their fees from their own pockets. A lack of sufficient finance could be seen as the reason for many students dropping out of their academic programmes, and being unable to return to school in the following academic year. When comparing the 2011 and 2012 academic years, below shows that generally very few students received financial assistance in both academic years. Among those who were enrolled, only $7.8 \%$ received a bursary or a fee reduction in 2012, compared to $8.5 \%$ in 2011. It appears that the rest of the students had to depend on either family, loans or other means of funding for their studies.

Approximately 22\% of households reported having paid absolutely nothing towards their children's fees. These households might either have no students attending higher education institutions or they might have received full bursaries or scholarships. It is noted that of those households who pay fees, the majority (16\%) paid R20,000 and above, whilst $12 \%$ paid between R4001 and R800o. Roughly 24\% of households paid between R8000 and $\mathrm{R} 20,000$, and $2 \%$ of households paid the minimum amount of R1 to R100. The results confirm that higher education in South Africa is quite expensive and if households are not financially able/empowered, their children might end up amongst the annual percentage of the unnecessary drop outs.

Table 4. Correlation between dependent and independent variables.

\begin{tabular}{llllll}
\hline \multicolumn{2}{l}{ Pearson's Correlation Coefficients, $N=4754$} & & \\
\hline \multicolumn{2}{l}{ Prob $>|r|$ under H0: Rho $=0$} & & & \\
\hline & Transport & Reason & Bursary & Fees & Distance \\
\hline Enrol & 0.80042 & -0.07016 & 0.24323 & 0.82160 & 0.79428 \\
& $<.0001$ & $<.0001$ & $<.0001$ & $<.0001$ & $<.0001$ \\
\hline
\end{tabular}

Source: Statistics South Africa (2012).

Table 4 shows the correlation of variables which test the strength and direction of a linear relationship between two variables on a scatter graph. It appears that tuition fees and transportation might have a strong relationship to enrolment given the correlation coefficient of 0.82 and 0.80 respectively. This means that the amount of fees that are owed as well as the mode of transportation to the registered institution can affect the enrolment rate. It is assumed that students with private transportation will find it easier to reach their institution than those using public transport. The distance travelled to the institution also plays a very significant part in enrolment rates. Bursaries or a fee reduction, by contrast, have a weak link to the enrolment rate given the correlation of 0.24 in Table 4 . 
Table 5 shows the constructs of the logistic regression model that identify the best combination of variables to predict circumstances which will affect enrolment figures at various higher education institutions. According to the data, it is noted that public and private transport are more likely to affect higher education institutions' enrolment rate, meaning that if the majority of students utilise such transportation, the rate of enrolment will ultimately peak. The figure reveals that students paying fees between R4001 and R12,000 per annum are the ones who are most likely to enrol. These students will make a positive impact on the enrolment rate in comparison to others. Students who spend 30 minutes or more travelling to their respective institutions are more likely to be enrolled than those that spend less time. The advantage being that they will arrive earlier for their classes. Consequently, such predictions escalate the enrolment rate if they are taken into consideration.

Table 6 shows some of the reasons for respondents' inability to enrol according to their racial groups. Black Africans, for example, had a higher percentage of unregistered potential students in comparison to other racial groups. It has also been noted that whites, Indians/Asians and coloureds have not experienced any major transportation difficulties, illnesses or unexpected pregnancies, whilst $100 \%$ of the black Africans have had such limitations facing them - making it difficult for them to register for tertiary education. From Table 6, it seems that all races experienced financial difficulties which prevented some of them from enrolling, with black Africans having 95\% of the share, whilst whites have $3 \%$, coloureds had $1 \%$ and Indian/Asian with $0.6 \%$. Approximately $58 \%$ of black Africans appeared to have no interest in pursuing their tertiary studies, followed by $31 \%$ of the whites, $10 \%$ of coloureds and $0.6 \%$ of Indians/Asians.

\section{Discussion}

The respondents' feelings or perceptions on the drop-out rates within the higher education institutions in the Gauteng province, indicate that higher education is vital in promoting employment opportunities, social equality and justice, and economic progress. Higher achievement level within higher education institutions is a key priority in any country. Assessing the scale and nature of drop out is particularly difficult, mainly because of the fact that data were not readily available when the researcher required it, and if it is available, the complexities and dynamics of such data can be defined and measured in different ways. Together with the available data on tertiary students' enrolment, extra data were collected to assess the respondents' perceptions regarding the higher education drop-out rate, and below are the findings. 
Table 5. Predictors of enrolment rate in the higher education institutions using logistic regression.

\begin{tabular}{|c|c|c|c|c|c|}
\hline \multicolumn{6}{|c|}{ Analysis of maximum likelihood estimates } \\
\hline \multirow[t]{2}{*}{ Parameter } & & \multirow[t]{2}{*}{ Estimate } & \multirow{2}{*}{$\frac{\text { Standard }}{\text { Error }}$} & \multirow{2}{*}{$\frac{\text { Wald }}{\text { Chi-Square }}$} & \multirow[t]{2}{*}{$\mathrm{Pr}>\mathrm{ChiSq}$} \\
\hline & & & & & \\
\hline Intercept & & 31.0195 & 213.7 & 0.0211 & 0.8846 \\
\hline Transport & Walking & -3.7347 & 290.9 & 0.0002 & 0.9898 \\
\hline Transport & Bicycle/motorcycle & -2.743 & 425.3 & 0 & 0.9949 \\
\hline Transport & Public vehicle & 12.078 & 174.4 & 0.0048 & 0.9448 \\
\hline Transport & Private vehicle & 12.1985 & 173.1 & 0.005 & 0.9438 \\
\hline Fees & None & $-|9.728|$ & 33.8676 & 0.3393 & 0.5602 \\
\hline Fees & RI-RI 000 & 0.8126 & 82.1418 & 0.0001 & 0.9921 \\
\hline Fees & RI00I-R4000 & 3.048 & 86.0153 & 0.0013 & 0.9717 \\
\hline Fees & R400I-RI2,000 & 4.659 & 107.3 & 0.0019 & 0.9654 \\
\hline Fees & $R / 2,000-R 20,000$ & 4.247 & 78.3552 & 0.0029 & 0.9568 \\
\hline Fees & $\mathrm{R} 20,000+$ & 4.0413 & 91.8081 & 0.0019 & 0.9649 \\
\hline Distance & Less than $15 \mathrm{~min}$ & 13.1545 & 381.9 & 0.0012 & 0.9725 \\
\hline Distance & $15-30 \mathrm{~min}$ & 17.1309 & 189.5 & 0.0082 & 0.928 \\
\hline Distance & $31-60 \mathrm{~min}$ & -2.5933 & 186.1 & 0.0002 & 0.9889 \\
\hline Distance & $61-90 \mathrm{~min}$ & -1.5853 & 238.1 & 0 & 0.9947 \\
\hline
\end{tabular}

Source: Statistics South Africa (2012).

From the acquired data, it appears that more than $30 \%$ of employed people felt that dropout rates in higher education institutions is not a problem, whilst the rest, $70 \%$, thought that drop out is a huge concern within the province's universities. The majority of the respondents stated that the main reason for university drop out is due to the lack of financial support, with $20 \%$ of the respondents thinking that a lack of ambition or focus as well as peer pressure are also reasons for high drop out. The participants were asked about measures that could help reduce the high drop-out rate within higher education. The majority of pensioners emphasised the need for students to stay away from drugs and bad friends and receive parental support, in addition to a general feeling that the government's financial support will serve as an important remedy. Very few respondents indicated that early career guidance could eliminate drop out, as a way of guiding students entering higher education towards their career choices and future opportunities. Once that insight has been received, it is assumed that many students will pursue their studies with passion and dedication.

In reference to the data analysis, Gauteng province results were not that impressive in terms of the tertiary enrolment - although there was a sliding scale of progress. The challenges facing the province may mean that the pressures experienced by young people in this province are relatively large. A lack of finance or focus around further education appears to be the driving force for many students quitting the tertiary sector or seeking available jobs in the Gauteng province. Further observations of the pedagogical literature regarding gender enrolment indicates that the female enrolment rate is progressively increasing from the 2010 academic year - similar statistics were also obtained in the 2007 academic year. According to the statistics published for the 2012 academic year, female students' enrolment rate in Gauteng was slightly lower in comparison to that of males. Looking into the reasons that potential students do not pursue tertiary education, the 2012 study indicates that the

\section{http://repository.uwc.ac.za}


majority of respondents declare that they have no money for fees, while others state that they had business arrangements or were working.

\begin{tabular}{|c|c|c|c|c|}
\hline $\begin{array}{l}\text { Reasons for not attending the higher } \\
\text { education institutions }\end{array}$ & $\begin{array}{l}\text { Black } \\
\text { African }\end{array}$ & Coloured & $\begin{array}{l}\text { Indian/ } \\
\text { Asian }\end{array}$ & White \\
\hline Too old/young & 81.3 & 3.7 & 0.0 & 15.0 \\
\hline $\begin{array}{l}\text { Has completed education/satisfied with my } \\
\text { level of education }\end{array}$ & 77.1 & 2.0 & 0.1 & 20.8 \\
\hline School/education institution is too far & 75.1 & 0.0 & 0.0 & 24.9 \\
\hline Difficulties to get to school (transport) & 100.0 & 0.0 & 0.0 & 0.0 \\
\hline No money for fees & 94.8 & 1.3 & 0.6 & 3.4 \\
\hline He or she is working at home or business/job & 75.8 & 3.0 & 3.6 & 17.6 \\
\hline Do not have time/too busy & 57.7 & 10.0 & 0.6 & 31.7 \\
\hline Family commitment (e.g. childminding) & 84.6 & 2.2 & 0.0 & 13.2 \\
\hline Education is useless or not interesting & 87.6 & 8.5 & 0.0 & 3.9 \\
\hline Unable to perform at school & 98.2 & 1.8 & 0.0 & 0.0 \\
\hline Illness & 100.0 & 0.0 & 0.0 & 0.0 \\
\hline Pregnancy & 100.0 & 0.0 & 0.0 & 0.0 \\
\hline Failed exams & 95.6 & 0.0 & 0.0 & 4.4 \\
\hline Got married & 70.3 & 12.1 & 0.0 & 17.7 \\
\hline Disability & 80.8 & 0.0 & 0.0 & 19.2 \\
\hline Not accepted for enrolment & 74.0 & 0.0 & 12.7 & 13.4 \\
\hline Other & 89.4 & 1.4 & 5.2 & 4.0 \\
\hline
\end{tabular}

Source: Statistics South Africa (20I2).

Approximately 92\% of the Gauteng students in the 2011 and 2012 academic years are reported to have received neither bursaries nor reduction in fees. The general feeling shared among the study's respondents was that higher education's drop-out rate seemed to be a huge concern in the Gauteng province. In this section, lack of finance was seen as the key reason for many tertiary students dropping out - which correlates with the quantitative analysis section of this study. Among the key points raised during this study, the researcher recommends that, in order to eliminate the high drop-out rate, students ought to stay away from drugs, focus on their studies and make good use of the government financial support systems in place to assist them. It is a common belief that breakthrough innovations in students' financial aid would serve as a remedy to the recurring drop-out rate in tertiary education in the province and across this multi-racial country of South Africa.

\section{Conclusion}

The enrolment rate revealed in the 2012 GHS study was extremely undesirable. However, with the addition of a new university in Gauteng in 2015, the participation rate in higher education institutions in the province is expected to improve. Tertiary education will not only benefit its alumni, but will ultimately make a huge impact in transforming the economy of the country through skills acquisition and retention. The study concludes that public and private transportation is more likely to affect enrolment. The model emphasises the importance of residing near to the institution of study. It is recommended that the focus of future research should be an extensive time-series analysis on higher education institutions' drop-out rate. This type of study could provide comparisons over the years

\section{http://repository.uwc.ac.za}


and will certainly give enhanced results on the drop-out trend. It is advisable that the primary data be collected directly from the institutions' records to avoid bias/inconsistency. Furthermore, it is also recommended that information concerning the new enrolment and racial proportion could be gathered from the institutions under study in order to obtain accurate outcomes.

\section{Funding}

This research received no specific grant from any funding agency in the public, commercial, or not-for-profit sectors.

\section{Note}

1. See http://interactive.statssa.gov.za:8282/webview/. 


\section{References}

Bloom DE, Canning D and Chan K (2006) Higher Education and Economic Development in Africa (Vol.102). Washington, DC: World Bank.

Bunting I, Sheppard C, Cloete N, et al. (2010) Performance Indicators in South African Higher Education 2000-2008. African Minds.

DHET (Department of Higher Education and Training) (2012a) Higher Education \& FET Colleges: Registration and Enrolments, Financial Exclusions, Allocation of Bursaries, Parliament Briefings.

DHET (Department of Higher Education and Training) (2012b) Green paper for post-school education and training. Available at: http://www.saqa.org.za/docs/papers/2012/greenpaper.pdf (accessed 17 March 2013).

Fisher G and Scott I (2011) Background paper 3: The role of higher education in closing the skills gap in South Africa. Closing the Skills and Technology Gap in South Africa.

Fisher G and Scott I (2011) Proposal for undergraduate curriculum reform in South Africa.

Fowler A and Gilfillan M (2003) A framework for stakeholder integration in higher education information systems projects. Technology Analysis and Strategic Management 15(4): 468-489.

Govender K (2013) 382 years for SA's top 5 research universities to transform. Available at: http://www. pretoria-news.co.za/382-years-for-sas-top-5-research-universities-totransform (accessed 11 November 2013).

HESA

(2009)

Available

at:

http://www.hesa.org.za/sites/hesa.org.za/files/hesa_press_release_-_nsc_results_

for_2009.pdf (accessed 15 November 2013).

Jenvey N (2013) Race 'equity index' for universities stirs controversy. Available at: http://www.university-worldnews.com/article.php?story=20131031122032172 (accessed 1 November 2013).

Letseka M and Maile S (2008) High University Drop-out Rates: A Threat to South Africa's Future. Pretoria: Human Sciences Research Council.

Macfarlane D (2006) Shock varsity dropout stats. Mail and Guardian, 28 September.

Makoe MQ (2006) South African distance students' accounts of learning in socio-cultural context: A habitus analysis. Race Ethnicity and Education 9(4): 361-380.

Mathabe N (2009) Mainstreaming gender into universities. A commentary by Professor N. Mathabe in UNISA. (accessed 23 August 2013).

Ministry of Education (2001) National plan for higher education in South Africa. Available at: $\quad$ http://www.oecd.org/southafrica/reviewsofnationalpoliciesforeducationsouthafrica.htm (accessed 13 March 2014).

Morrow WE (1990) Aims of education in South Africa. International Review of Education 36(2): 171-181. Mubangizi JC and Mubangizi BC (2005) Poverty, human rights law and socio-economic realties in South Africa. Development South Africa 22(2): 277290.

Nimubona A and Vencatachellum D (2007) Intergenerational education mobility of black and white South Africans. Journal of Population Economics 20(1): 149-182. 
Pierrakeas C, Xeno M, Panagiotakopoulos C, et al. (2004) A comparative study of dropout rates and causes for two different distance education courses. The International Review of Research in Open and Distributed Learning 5(2): 231-33.

Ratele K and Shefer T (2003) Bodies and apartheid. In: Ratele K and Duncan N (eds) Social Psychology: Identities and Relationships. South Africa: UCT Press, pp. 88105 .

Statistics South Africa (2012). Statistics South Africa. Available at: http://www.statssa.gov.za/publications/ SAStatistics/SAStatistics2012.pdf (accessed 15 January 2013).

Steyn DG and de Villiers P (2006) The impact of changing funding sources on higher education institutions in South Africa. Council on Higher Education.

Steyn AGW (2009) Measuring student participation in the higher education sector in SA. The International Education Association of South Africa, 2013. Higher Education in Context. Available at: http://ufisa.aalto.fi/en/network/cput/facts_figures_section.pdf (accessed 25 August 2013).

\section{Author biographies}

Mpho Joyce Matsolo is a Research Scholar in the Department of Statistics and Population Studies at the University of the Western Cape, Cape Town, South Africa.

Wilson CNingpuanyeh recently completed a Ph.D. in Population Studies in the Faculty of Natural Sciences (Department of Statistics and Population Studies) at the University of the Western Cape, Cape Town, South Africa.

Appunni Sathiya Susuman has an MA and MPhil in Population Studies and a Ph.D. in Demography. He has expertise in fertility, mortality, technical demography, public health, population policy and social sciences. At present he is working as an associate professor in the Faculty of Natural Sciences (Department of Statistics and Population Studies) at the University of the Western Cape, Cape Town, South Africa. Professor Sathiya has more than 50 publications in refereed journals and has recently published a book on African population studies. 